\title{
Inhibition of cathepsin L sensitizes human glioma cells to ionizing radiation in vitro through NF-KB signaling pathway
}

\author{
Neng YANG\#, Pan WANG\#, Wen-juan WANG, Yun-zhen SONG, Zhong-qin LIANG* \\ Department of Pharmacology, College of Pharmaceutical Sciences, Soochow University, Suzhou 215123, China
}

\begin{abstract}
Aim: Cathepsin L, a lysosomal cysteine proteinase, is exclusively elevated in a variety of malignancies, including gliomas. In this study we investigated the relationship between cathepsin $\mathrm{L}$ and $\mathrm{NF}-\mathrm{kB}$, two radiation-responsive elements, in regulating the sensitivity of human glioma cells ionizing radiation (IR) in vitro.

Methods: Human glioma U251 cells were exposed to IR (10 Gy), and the expression of cathepsin L and NF-KB was measured using Western blotting. The nuclear translocation of NF-KB p65 and p50 was analyzed with immunofluorescence assays. Cell apoptosis was examined with clonogenic assays. NF-KB transcription and NF-KB-dependent cyclin D1 and ATM transactivation were monitored using luciferase reporter and ChIP assays, respectively. DNA damage repair was investigated using the comet assay.

Results: IR significantly increased expression of cathepsin L and NF-kB p65 and p50 in the cells. Furthermore, IR significantly increased the nuclear translocation of NF-KB, and NF-kB-dependent cyclin D1 and ATM transactivation in the cells. Knockdown of p65 did not change the expression of cathepsin L in IR-treated cells. Pretreatment with Z-FY-CHO (a selective cathepsin L inhibitor), or knockdown of cathepsin L significantly attenuated IR-induced nuclear translocation of NF-KB and cyclin D1 and ATM transactivation, and sensitized the cells to IR. Pretreatment with Z-FY-CHO, or knockdown of p65 also decreased IR-induced DNA damage repair and clonogenic cell survival, and sensitized the cells to IR.

Conclusion: Cathepsin L acts as an upstream regulator of NF-KB activation in human glioma cells and contributes to their sensitivity to IR in vitro. Inhibition of cathepsin L can sensitize the cells to IR.
\end{abstract}

Keywords: glioma; radiotherapy; ionizing radiation; cathepsin L; NF-kB; cyclin D1; ATM; Z-FY-CHO; shRNA; DNA damage; clonogenic survival

Acta Pharmacologica Sinica (2015) 36: 400-410; doi: 10.1038/aps.2014.148; published online 9 Feb 2015

\section{Introduction}

Radiotherapy is commonly used in cancer management, with $40 \%-60 \%$ of all cancer patients receiving radiation treatment ${ }^{[1]}$. Radiotherapy is considered mandatory for glioblastoma patients ${ }^{[2]}$. However, the development of radioresistance remains a significant therapeutic hindrance and limits the effectiveness of ionizing radiation (IR) in treating patients with glioma $^{[1,3]}$.

The stress-inducible transcription factor nuclear factor (NF)$\kappa \mathrm{B}$ regulates genes involved in an array of physiological and pathological processes, including cell cycle control, proliferation, cell growth, metastasis, inflammation, apoptosis, and oncogenic activation of human cancers; it has also been impli-

\footnotetext{
"These authors contributed equally to this article.

* To whom correspondence should be addressed.

E-mail liangzhongqin@suda.edu.cn

Received 2014-03-24 Accepted 2014-08-16
}

cated as a determinant of radiosensitivity ${ }^{[4,5]}$. NF- $\mathrm{KB}$ is the heterodimeric complex of Rel family proteins (p65, p50, p52, c-Rel, and RelB) that interacts with the inhibitor of $\kappa B$ (ІкB) proteins in the cytoplasm. The active complex of NF-KB is composed of two subunits: p65 and $\mathrm{p} 50^{[6,7]}$. When the canonical NF-KB pathway is stimulated, several signaling cascades converge at IKK, the inhibitor of the kappa-B kinase complex, which phosphorylates and degrades $\mathrm{I} \mathrm{KBa}$, thereby promoting the nuclear translocation of NF-KB to activate the expression of specific target genes ${ }^{[8]}$. NF-KB activity is known to be induced by IR in human glioma cells ${ }^{[9,10]}$. Aberrant NF-KB activation contributes to radioresistance ${ }^{[11,12]}$, and the loss or inhibition of NF-KB has been shown to sensitize many different tumor types to $\mathrm{IR}^{[5,13-15]}$. NF-KB is known to be an important mechanism for conferring resistance to radiotherapy. There is also increasing evidence that inhibiting NF- $\mathrm{kB}$ is an attractive target for cancer therapeutics ${ }^{[16]}$.

Cathepsin L (CTSL), a lysosomal cysteine proteinase, is 
reported to be upregulated in a variety of malignancies: breast, lung, gastric, colon, head and neck carcinomas, melanomas, and gliomas ${ }^{[17-19]}$. Research supports the notion that increased cathepsin L expression is involved in tumor progression, including cell apoptosis and cell cycle, because it is able to degrade nuclear transcription factors ${ }^{[20,21]}$. Cathepsin $\mathrm{L}$ is a survival protein that confers resistance to cancer cell apopto$\operatorname{sis}^{[22,23]}$. The expression of cathepsin $\mathrm{L}$ is exclusively elevated in cancer cells and can be easily screened for small-molecule inhibitors ${ }^{[24,25]}$; therefore, it may serve as a better therapeutic target than other cathepsins ${ }^{[26-28]}$.

We have recently proven that the inhibition of cathepsin $\mathrm{L}$ can block the nuclear translocation of NF-kB in neuroblastoma cells ${ }^{[29]}$ and, furthermore, that cathepsin $L$ contributes to quinolinic acid (QA)-induced NF- $\mathrm{kB}$ activation in rat striatal neurons ${ }^{[30]}$. Ongoing work in our laboratory indicates that IR increases cathepsin L expression and that it is involved in the radioresistance of glioma cells. The results presented here lead us to hypothesize that cathepsin $\mathrm{L}$ can regulate radiationinduced NF-KB activation. To further investigate the relationship between these two radiation-responsive elements in tumor cells and to determine a possible mechanism regulating their modulation, cathepsin L and NF-kB were each inhibited to determine the effect on each other and on the radiosensitization of U251 cells.

\section{Materials and methods Cell lines}

U251 human glioma cells were cultured in DMEM medium (Gibco Life Technologies, Paisley, UK) supplemented with $10 \%$ fetal bovine serum (Gibco Life Technologies).

\section{Antibodies and reagents}

Cathepsin L inhibitor II (Z-FY-CHO) was purchased from Calbiochem (La Jolla, CA, USA). Rabbit anti-NF-kB p65-ChIP antibodies and monoclonal mouse anti-cathepsin $\mathrm{L}$ antibodies were purchased from Abcam (Cambridge, UK). Polyclonal rabbit anti-p65 antibodies and a polyclonal rabbit IкBa antibody was purchased from Cell Signaling Technology (Beverly, MA, USA). Monoclonal mouse anti- $\beta$-actin antibody and rabbit anti-lamin B antibody were purchased from MultiSciences (MultiSciences Biotech Co, Shanghai, China). Monoclonal mouse anti-p50 antibody was purchased from Santa Cruz Biotechnology (Santa Cruz, CA, USA).

\section{shRNA transfection}

Human cathepsin L shRNA, NF-kB p65 shRNA and control shRNA were purchased from Santa Cruz Biotechnology. One day before transfection, U251 cells were seeded in sixwell plates and grown in $2 \mathrm{~mL}$ of DMEM supplemented with $10 \%$ FBS. After $24 \mathrm{~h}$ in culture, shRNA plasmid DNA was transfected into cells with an shRNA Transfection Reagent kit according to the manufacturer's protocol, and the cells were then subjected to different treatments. Cells were lysed and protein extracts were isolated and utilized to detect cathepsin $\mathrm{L}, \mathrm{NF}-\mathrm{kB}$, and $\beta$-actin expression by Western blot analysis as described below.

\section{Western blotting}

Cells were seeded in DMEM containing 10\% FBS for $24 \mathrm{~h}$. Cells were then lysed in $50 \mathrm{mmol} / \mathrm{L} \mathrm{HEPES} \mathrm{(pH} \mathrm{7.4),} 150$ $\mathrm{mmol} / \mathrm{L} \mathrm{NaCl}, 100 \mathrm{mmol} / \mathrm{L} \mathrm{NaF}, 1 \mathrm{mmol} / \mathrm{L} \mathrm{MgCl}_{2}, 1.5$ mmol/L EGTA, 10\% glycerol, 1\% Triton X-100, 1 g/mL leupeptin, and $1 \mathrm{mmol} / \mathrm{L}$ PMSF. Equal quantities of protein (40 $\mu \mathrm{g}$ ) were separated by electrophoresis on a $12 \%$ SDS-PAGE gel and transferred to $0.45 \mu \mathrm{m}$ nitrocellulose transfer membranes. The expression of cathepsin L, p65, p50, IкBa, $\beta$-actin and lamin $\mathrm{B}$ were identified by a reaction with specific primary antibodies (as described above) for $15 \mathrm{~h}$, followed by washing 3 times with TBST and incubation for $1 \mathrm{~h}$ with secondary antibodies. After washing 3 times with TBST, reactive bands were detected by the Odyssey Infrared Imaging System (LI-COR Biosciences, Lincoln, NE, USA).

\section{Immunofluorescence assay}

The localization of NF-kB protein in U251 cells was investigated using the immunofluorescence-staining assay. Cells were grown on glass disks in 24-well plates and then treated with either 10 Gy irradiation, $12 \mathrm{~h}$ incubation with $10 \mu \mathrm{mol} / \mathrm{L}$ Z-FY-CHO/shRNA cathepsin L or a combination of these two treatments. At $24 \mathrm{~h}$ after treatment, the glass disks were removed from the wells, washed with PBS, and fixed with cold methanol. After blocking with 1\% BSA, the cells were incubated with rabbit anti-NF- $\mathrm{B}$ antibody followed by an anti-rabbit secondary fluorescent antibody. Cells were then stained with DAPI in the dark. Images were captured using a laser scanning TCS SP2 confocal microscope (Leica).

\section{Luciferase reporter gene assay}

The pGL4.32 [luc2P/NF-kB-RE/Hygro] vector (a-f) contains five copies of an NF- $\mathrm{KB}$ response element (NF-kB-RE) that drives the transcription of the luciferase reporter gene luc2P (Photinus pyralis). Cells were seeded in 24-well plates and incubated for $24 \mathrm{~h}$. The next day, cells were transiently cotransfected with the promoter sequence-inserted luciferase pGL4.32 [luc2P/NF-kB-RE/Hygro] vector and the control pRL-TK vector (Promega, Madison, WI, USA) with Lipofectamine 2000 reagent (Invitrogen, NY, USA) $12 \mathrm{~h}$ before IR. Luciferase activity of the transfected cells was assayed using a dual-luciferase reporter assay kit (Promega) and luminometer (Infinite M200 plate counter, Tecan, Männersdorf, Switzerland). Relative luciferase activity was presented as the ratio of firefly units to renilla units.

\section{Chromatin immunoprecipitation (ChIP) assay}

U251 cells were cultured for $24 \mathrm{~h}$ before treatment with IR. Soluble chromatin was crosslinked by adding it to formaldehyde at $37^{\circ} \mathrm{C}$ for $10 \mathrm{~min}$. Chromatin was sheared by sonication, and DNA fragments with sizes between 0.2 and $0.7 \mathrm{~kb}$ were obtained. Immune complexes were immunoprecipitated using anti-p65 or an IgG control antibody. Protein-DNA cross-links were then reverted at $65^{\circ} \mathrm{C}$ overnight. DNA was 
purified and then subjected to PCR with primers specific for the gene promoter region encompassing the NF- $\mathrm{KB}$ binding site. Sequences of promoter-specific primers are as follows: GAPDH, 5'-GGACTCATGACCACAGTCCAT-3' (forward) and 5'-GTTCAGCTCAGGGATGACCTT-3' (reverse); Cyclin D1, 5'-TCAGGGATGGCTTTTGGG-3' (forward) and 5'-CAACTTCAACAAAACTCCCC-3' (reverse); ATM, 5'-GCAGTTTAAGCCTCTTTGTATG-3' (forward) and 5'-CCTGACTTTCCTTCCGAATC-3' (reverse).

\section{Comet assay}

DNA damage at the individual cell level following IR treatment was quantified using an alkaline comet assay. Cell suspensions were mixed with low melting point agarose, embedded onto a frosted glass slide pre-coated with a $0.8 \%$ layer of normal melting point agarose, allowed to gel at $4{ }^{\circ} \mathrm{C}$, gently topped with another $0.8 \%$ normal melting point agarose layer and covered with a coverslip. After the gel solidified, the coverslip was removed. Following lysis, slides were washed and subjected to electrophoresis under alkaline conditions at $20 \mathrm{~V}$ for $40 \mathrm{~min}$. They were then fixed, dried, and stained with 50 $\mu \mathrm{L}$ of $5 \mathrm{mg} / \mathrm{L}$ ethidium bromide. An Olympus CKX31 fluorescence microscope (10×objective) was used to capture images. Comet data were collected by visual scoring. Subsequent time points are expressed as a percentage of the 0 time point.

\section{Radiation treatment and clonogenic survival assay}

Cells were seeded in six-well plates at a density of $2 \times 10^{2}$ cells per well. After an overnight incubation, the cells were pretreated with $10 \mu \mathrm{mol} / \mathrm{L}$ Z-FY-CHO or cathepsin L shRNA/ p65 shRNA for $12 \mathrm{~h}$ and exposed to different doses of radiation with 6-MV X-rays from a linear accelerator (PRIMUS, DE, Siemens A\&D LD, Nelson Avenue Concord, USA) at a dose rate of $198 \mathrm{cGy} / \mathrm{min}$ followed by incubation at $37^{\circ} \mathrm{C}$ for $9 \mathrm{~d}$. Colonies were fixed and stained with $0.5 \%$ crystal violet (Sigma Aldrich). The surviving fraction was determined by the proportion of seeded cells that formed colonies following irradiation relative to untreated cells.

\section{Statistical analysis}

Data are expressed as the mean \pm SD. At least 3 independent experiments were performed. Differences in measured variables between the experimental and control groups were assessed by Student's $t$-test. $P$ values less than 0.05 were considered statistically significant. All analyses were performed with GraphPad Prism 5.0.

\section{Results}

Increased protein expression of cathepsin $L$ and nuclear translocation of NF-kB p65 and p50 in glioma U251 cells following IR To determine the effect of IR on cathepsin L expression and its role in determining IR sensitivity in cancer cells, we first examined the expression level of cathepsin $\mathrm{L}$ in whole cells at various time points following their exposure to IR. The treatment of U251 cells with IR caused a dose-dependent activation of cathepsin L as evidenced by Western blot analysis. The expression of cathepsin L (26 kDa) in U251 cells increased at approximately $30 \mathrm{~min}$ following exposure to IR (Figure 1A). Furthermore, clear nuclear translocation of IR-induced cathep$\sin \mathrm{L}$ was observed (Figure 1B). The stimulative effect of IR on NF-kB activation was also verified by Western blot analysis. NF-kB nuclear protein was demonstrably increased in tumor cells treated with IR. IR activated both NF-kB p65 and p50 in U251 cells in a time-dependent manner, reaching maximum activation at $2 \mathrm{~h}$ and returning to control levels by $8 \mathrm{~h}$ (Figure 1C). Moreover, IR induced the nuclear translocation of p65 and p50 in U251 cells in a dose-dependent manner $2 \mathrm{~h}$ postIR (Figure 1D). These results clearly show that IR activates cathepsin $\mathrm{L}$ and induces the nuclear translocation of NF- $\mathrm{kB}$. However, whether cathepsin L is directly involved in the regulation of $\mathrm{NF}-\mathrm{kB}$ remains to be explored. The maximum activation of NF-kB in U251 cells was at $2 \mathrm{~h}$ following IR (10 Gy); therefore, this IR dose and timepoint were chosen for the following experiments.

\section{Inhibition of cathepsin L sensitizes glioma U251 cells to IR}

To further determine the role of cathepsin L in IR sensitivity of tumor cells, we suppressed cathepsin L by using the inhibitor Z-FY-CHO or cathepsin L shRNA before subjecting the cells to a series of IR dosages. Colony-forming assays demonstrated that Z-FY-CHO sensitizes U251 cells to IR (Figure 2A). Next, cathepsin L expression in U251, U251-consh (cells transfected with control shRNA) and U251-Lsh (cells transfected with cathepsin L shRNA) cells confirmed the knockdown of cathepsin L expression (Figure 2B). U251-Lsh cells were more sensitive than U251-consh cells to IR (Figure 2C). Figure 2 demonstrates that the inhibition of cathepsin L in U251 cells augmented the colony-inhibiting effect of IR. These results indicate that IR-stimulated cathepsin $\mathrm{L}$ had a protective role in tumor cells, contributing to their growth, survival, and resistance to radiotherapy.

Inhibition of cathepsin L using Z-FY-CHO or cathepsin L shRNA reduced IR-induced nuclear translocation of NF-kB

Because cathepsin $\mathrm{L}$ was shown to have a prosurvival role in tumor cells treated with IR (Figure 1 and 2), we wanted to determine whether there was an association between the function of cathepsin L and the activity of NF- $\mathrm{kB}$ in the radioresistance of U251 cells. As shown above, nuclear translocation of p65 and p50 in U251 cells increased $2 \mathrm{~h}$ post-IR (10 Gy), while IR-induced activation of p65 and p50 in U251 cells was partially blocked by Z-FY-CHO (Figure 3A). The effect of Z-FY$\mathrm{CHO}$ on IR-induced nuclear translocation of p65 was more clearly observed by immunofluorescence (Figure 4A). Parallel to changes in NF- $\mathrm{kB}$ activation, the partial degradation of I $\mathrm{Ka}$ by IR was also reduced using Z-FY-CHO (Figure 3A). Similarly, IR-induced activation of NF-kB in U251-Lsh cells was less evident than in U251-consh cells (Figure 3B and 4B). Consistent with the altered p65 and p50 activation, IR triggered less degradation of IKBa in U251-Lsh cells compared to U251consh cells (Figure 3C). These data indicate that cathepsin L plays such a critical role in the IR-induced activation of NF- $\mathrm{KB}$ 
A
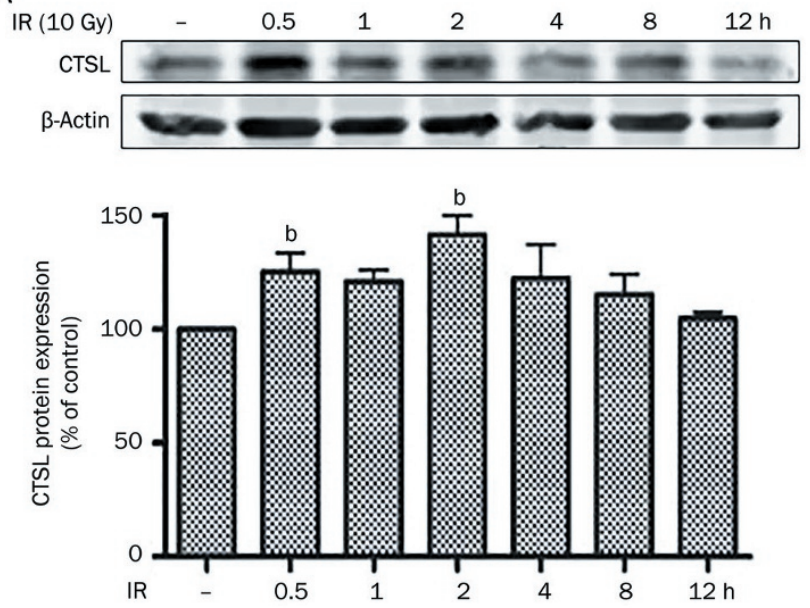

C
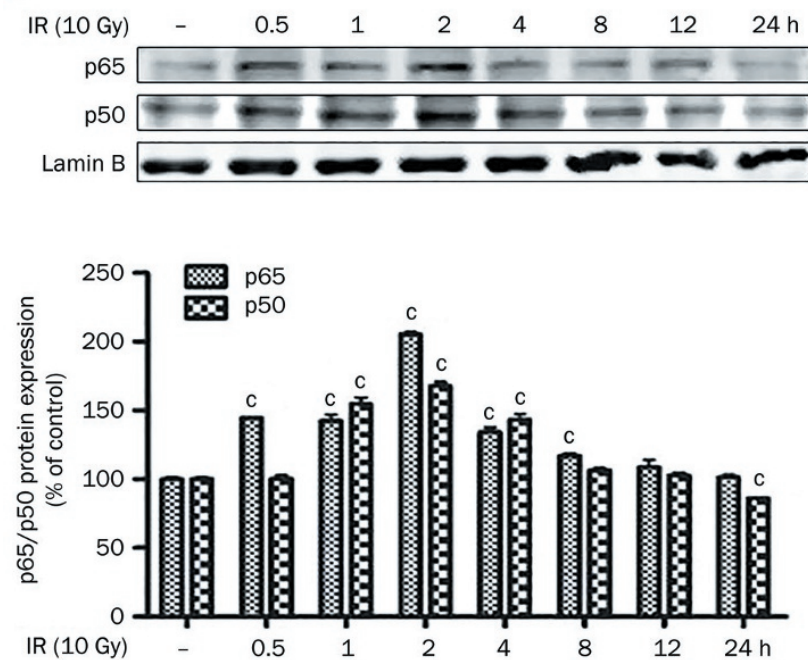

B
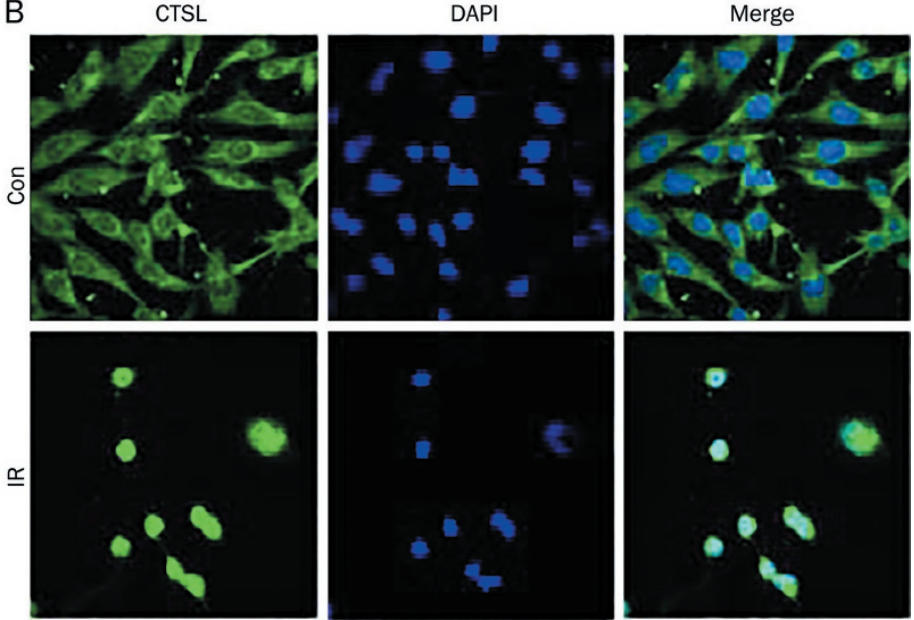

D
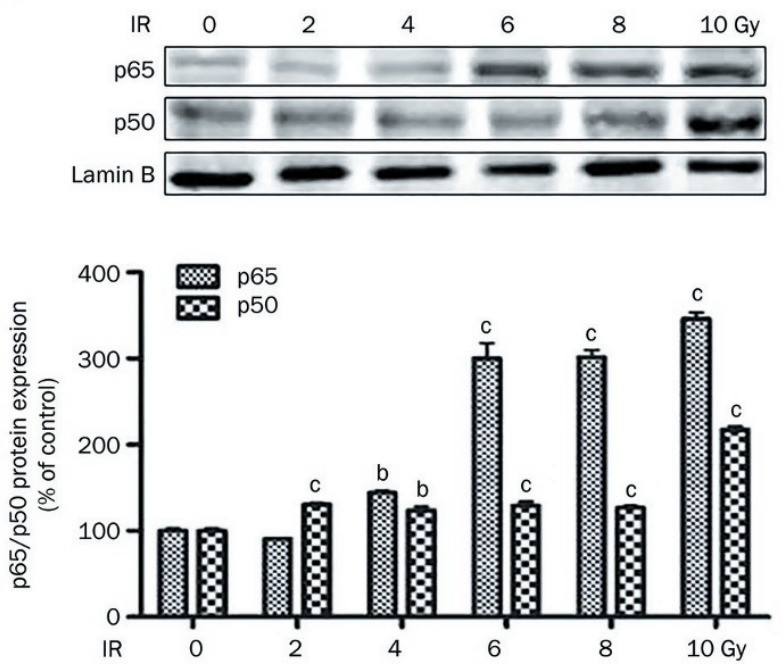

Figure 1. The expression of cathepsin L protein and nuclear translocation of NF-KB p65 and p50 in U251 cells following IR was analyzed by Western blot. (A) Western blot analysis of cathepsin L in U251 cells treated with IR (10 Gy). $\beta$-Actin was used as an internal control. ${ }^{b} P<0.05$, ${ }^{c} P<0.01$ vs control. (B) Immunofluorescence assay of cathepsin L expression in U251 cells treated with IR (10 Gy). (C) Western blot analysis of the nuclear translocation of NF-KB in U251 cells treated with IR (10 Gy). Lamin B was used as a nuclear internal control. ${ }^{\mathrm{b}} P<0.05,{ }^{\mathrm{c}} P<0.01$ vs control. (D) Western blot analysis of NF-KB expression in the nucleus of U251 cells following various doses of IR. Lamin B was used as a nuclear internal control. ${ }^{\mathrm{b}} P<0.05$, ${ }^{\mathrm{C}} P<0.01 \mathrm{vs}$ control.

that it could be a mediator of NF-kB-mediated radioresistance in U251 cells.

Z-FY-CHO and cathepsin L shRNA inhibit IR-induced NF-KB dependent transcriptional activation

We investigated the ability of p65 to bind its consensus sequence in U251 cells, U251-consh and U251-Lsh cells following IR using a luciferase-reporter assay. IR did not influence the expression of the internal control plasmid used to monitor transfection efficiency (data not shown). Consistent with increased DNA binding, the luciferase expression in U251 cells increased following IR and could be partially blocked by Z-FYCHO (Figure 5A). Similarly, luciferase expression post-IR in
U251-consh cells was higher than in U251-Lsh cells (Figure $5 \mathrm{~B})$. ChIP analysis was used to determine whether radiationinduced NF- $\mathrm{KB}$ enhances its downstream target genes Cyclin D1 and ATM. The recruitment of p65 to both the Cyclin D1 promoter (Figure 5C) and ATM promoter (Figure 5D) was significantly enhanced in U251-consh cells after exposure to IR compared to U251-Lsh cells, as expected. Thus, inhibition of cathepsin L blocked the activation and transcription of NF- $\mathrm{KB}$ in U251 cells treated with IR. In these experiments, suppression of cathepsin L by Z-FY-CHO or cathepsin L shRNA in IRtreated cells suggests that cathepsin L plays a key role in the regulation of IR-induced $\mathrm{NF}-\mathrm{kB}$ transcriptional activity. 
A
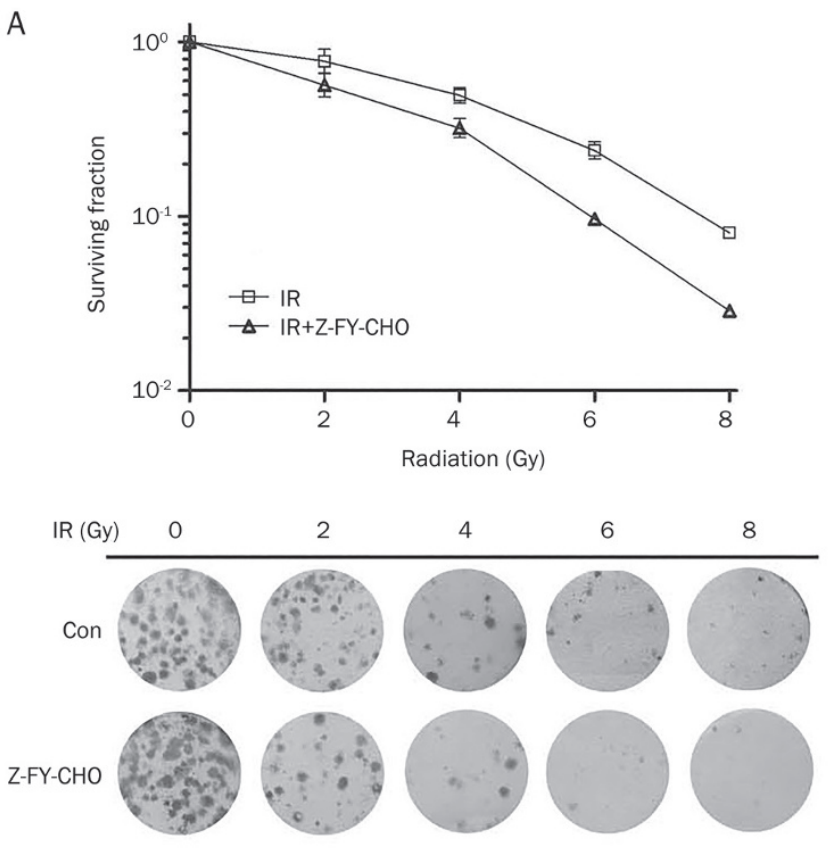

B

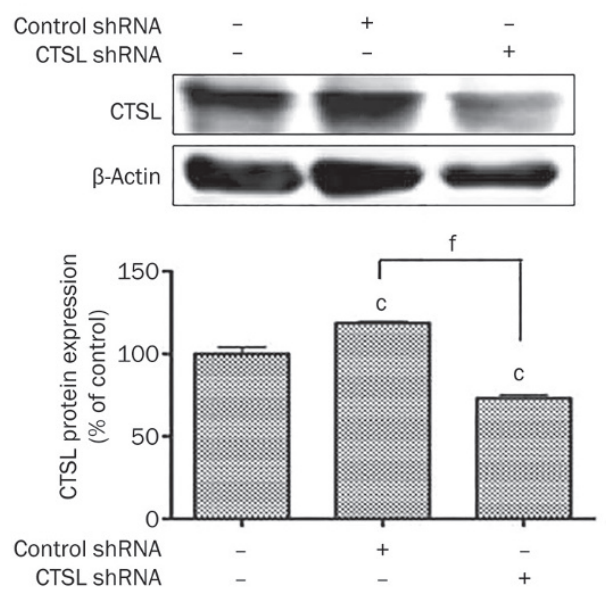

NF-KB inhibition sensitizes U251 cells to IR without affecting cathepsin L

After showing that cathepsin $\mathrm{L}$ is required for the expression and translocation of NF-kB in IR-treated cells (Figures 3, 4 and $5)$, we next determined the effect of NF-KB on cathepsin L. p65 expression analysis in U251 cells, U251-consh and U251p65sh cells confirmed the efficiency of p65 knockdown (Figure $6 \mathrm{~A})$. An increase in cathepsin $\mathrm{L}$ expression $(26 \mathrm{kDa})$ could be observed starting $30 \mathrm{~min}$ after IR exposure (Figure 1A). Thus, we compared the expression of cathepsin L in U251-p65sh (cells transfected with p65 shRNA) and U251-consh cells 30 min following control or IR exposure; no obvious change between these two types of cells was observed (Figure 6B). This suggests that $\mathrm{p} 65$ knockdown has no evident effect on the expression of cathepsin L $(26 \mathrm{kDa})$. These results suggest that, in IR-treated U251 cells, cathepsin L acts as an upstream regulator of NF-kB activation. The alkaline comet assay was used
C
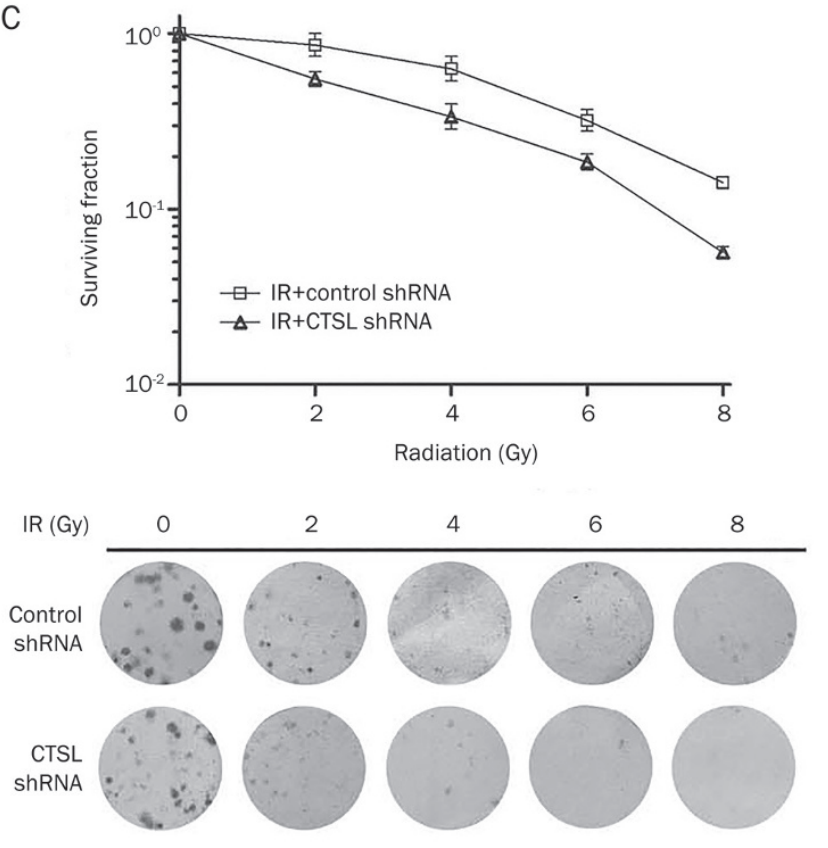

Figure 2. The inhibition of cathepsin $L$ sensitized $U 251$ cells to IR. (A) Clonogenic survival curves for U251 cells treated with radiation $(0,2,4,6$, and $8 \mathrm{~Gy}$ ) alone or in combination with Z-FY-CHO. (B) Western blot of CTSL in whole cell extracts from parental U251, U251-consh and U251-Lsh cells. $\beta$-Actin was used as an internal control. ${ }^{c} P<0.01$ vs U251. ${ }^{f} P<0.01$ vs U251-consh group. (C) Clonogenic survival curves for U251-consh and U251-p65sh cells treated with radiation (0, 2, 4, 6, and 8 Gy).

to examine IR-induced single-strand break (SSB) formation and repair at the individual cell level (Figure 6C). Clonogenic assays also showed that reduced NF-kB expression is correlated with radiation-induced apoptosis, thereby sensitizing U251 cells to IR (Figure 7). These results provide evidence that direct inhibition of cathepsin L in U251 cancer cells is capable of enhancing radiation-induced cell death through the NF-kB signaling pathway.

\section{Discussion}

This study determined that cathepsin $\mathrm{L}$ acts as a regulator of NF-kB during radiotherapy of U251 cells. The expression of cathepsin L (26 kDa) and nuclear translocation of NF-KB increased significantly after exposure to IR in U251 cells. Additionally, in line with our hypothesis, the expression of cathepsin $\mathrm{L}$ increased prior to the nuclear translocation of NF-KB. 
A
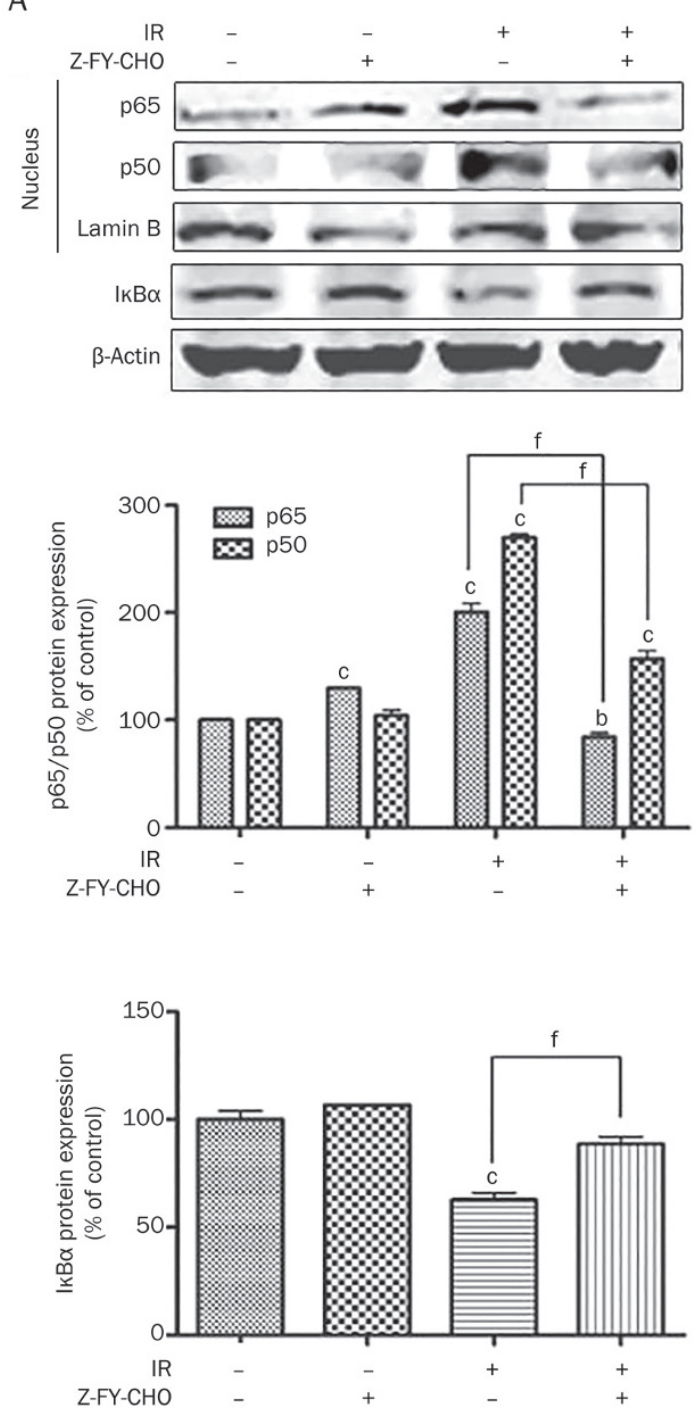

B
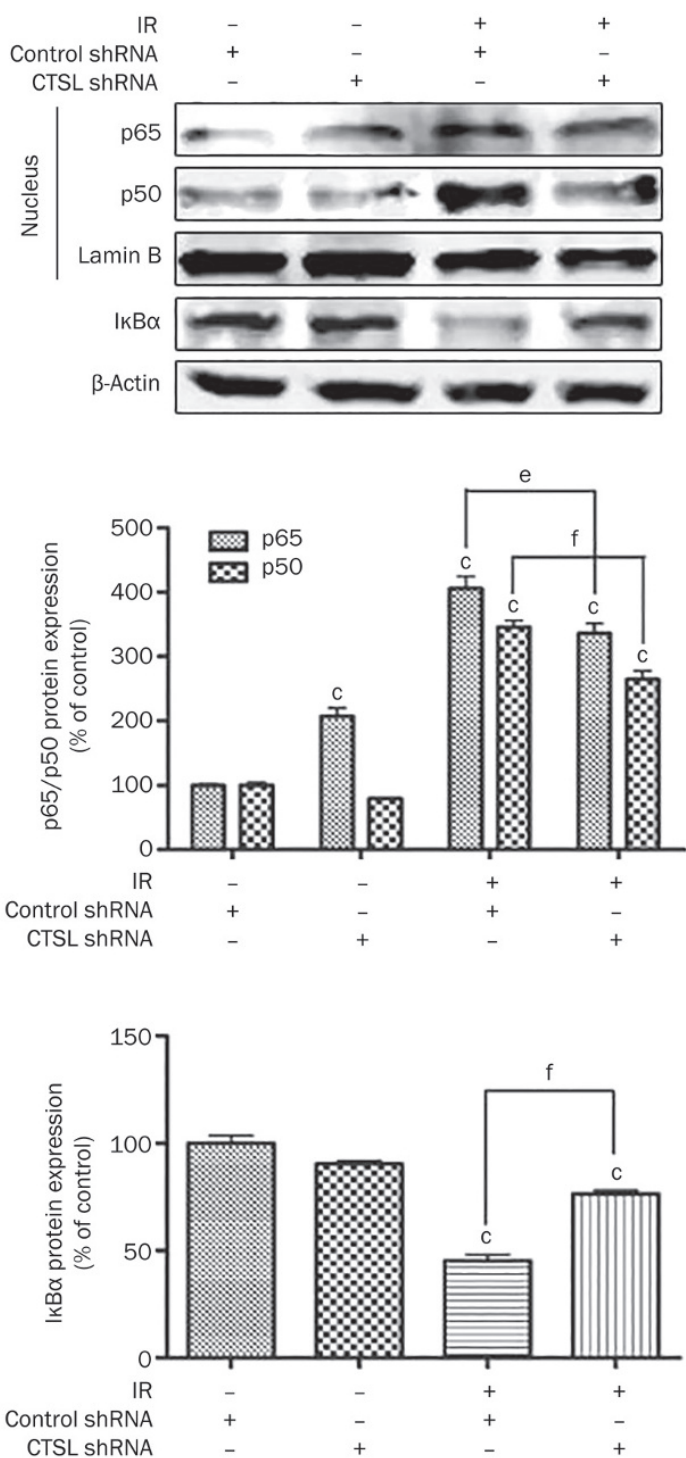

Figure 3. Altered IR-induced nuclear translocation of NF-KB following selective inhibition of cathepsin L with Z-FY-CHO or cathepsin L shRNA. (A) Western blot analysis of IkB $\alpha$ expression and the nuclear translocation of NF-kB in U251 cells treated with Z-FY-CHO, IR, or both. Lamin B was used as a nuclear internal control. ${ }^{\mathrm{b}} P<0.05,{ }^{\mathrm{C}} P<0.01$ vs control. ${ }^{\mathrm{e}} \mathrm{P}<0.05,{ }^{\mathrm{f}} P<0.01$ vs IR alone group. (B) Western blot analysis of the nuclear translocation of NF-KB in U251-consh and U251-Lsh cells treated with IR (10 Gy). Lamin B was used as a nuclear internal control. ${ }^{\mathrm{C}} P<0.01$ vs control. ${ }^{\mathrm{e}} P<0.05$, ${ }^{\mathrm{f}} P<0.01$ vs IR alone group.

To investigate whether cathepsin $\mathrm{L}$ is involved in the activation of NF-KB, we reduced cathepsin L expression by treating U251 cells with the selective cathepsin L inhibitor Z-FYCHO $12 \mathrm{~h}$ prior to radiation, or by transfecting the U251 cells with cathepsin L shRNA to establish a stable, low cathepsin L-expressing cell line using hygromycin selection. IR-induced nuclear translocation of NF-KB was reduced when the expression of cathepsin $\mathrm{L}$ was decreased based on Western blotting and immunofluorescence assays. NF-KB-dependent transcriptional activation was impaired in U251 cells following IR as measured by a dual-luciferase reporter assay. Furthermore, results of ChIP assays are congruent with the hypothesis that the inhibition of cathepsin L blocks the binding activity of
NF- $\mathrm{KB}$ to its target genes Cyclin D1 and ATM following IR. The inhibition of cathepsin L increased the radiosensitivity of U251 cells to IR by reducing IR-induced DNA damage repair and clonogenic cell survival. Altogether, the above data demonstrates that the inhibition of cathepsin $\mathrm{L}$ reduces radiationinduced NF-KB activation, which is involved in radioresistance, thereby improving the sensitivity of U251 cells to ionizing radiation.

Some studies have discovered a regulatory loop in which cathepsin $\mathrm{L}$ acts as a downstream target gene of NF- $\mathrm{kB}$ in murine $\mathrm{C} 2 \mathrm{C} 12$ cells. In this model, cathepsin $\mathrm{L}$ is downregulated when IкB $\beta$ was silenced ${ }^{[31,32]}$. These studies were focused on NF-kB-mediated modulation of cathepsin L, but cathepsin 
A $\quad$ p65
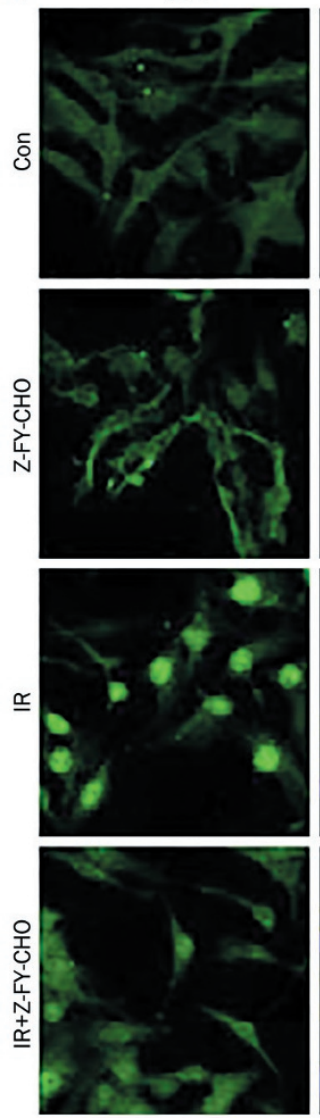

DAPI
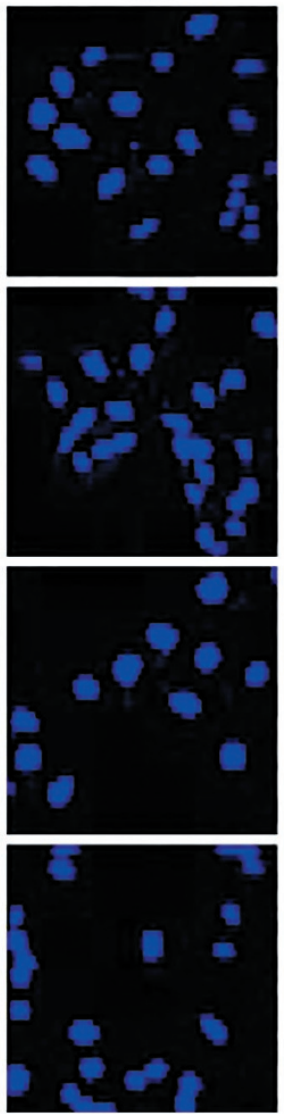
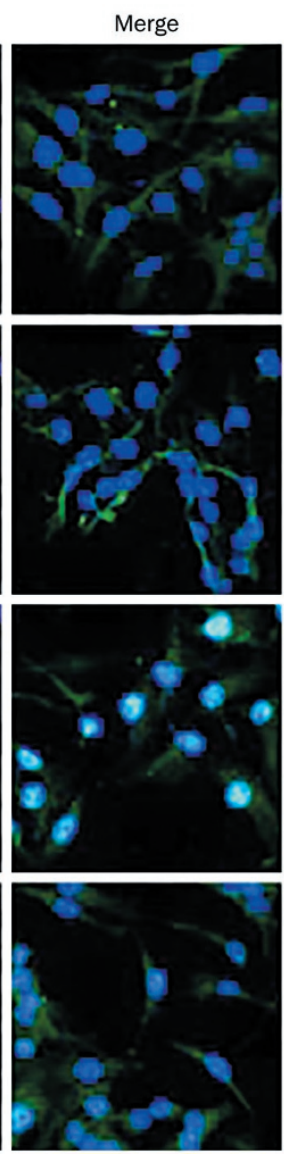

B
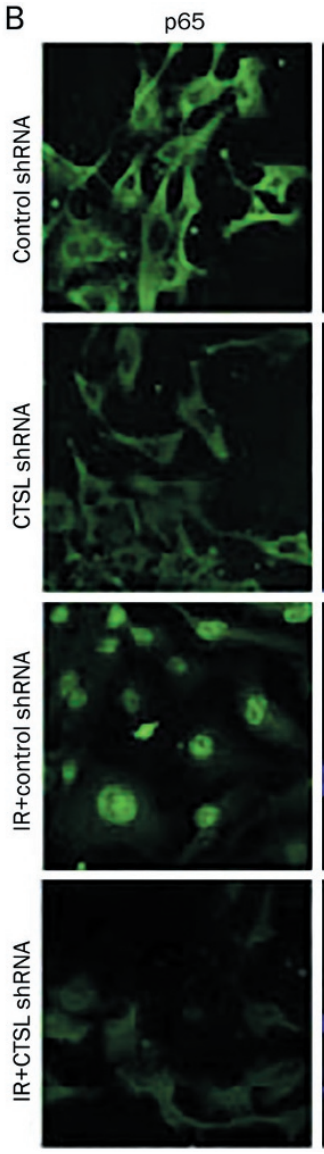
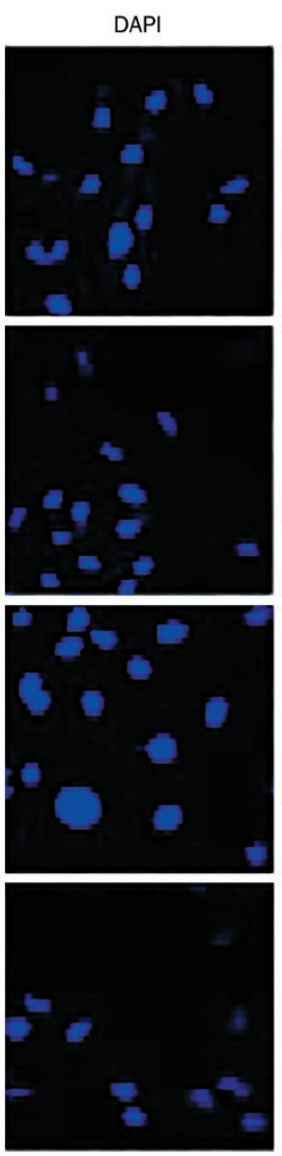
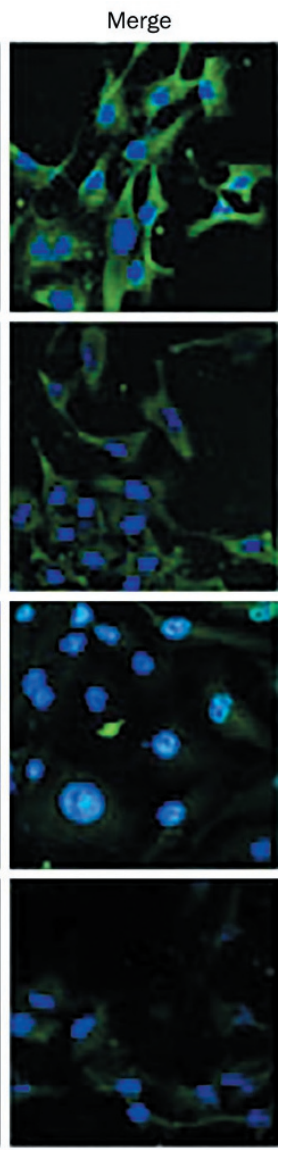

Figure 4. Altered IR-induced nuclear translocation of NF-KB following selective inhibition of cathepsin L with Z-FY-CHO or cathepsin L shRNA. (A) p65 protein immunofluorescence in U251 cells treated with Z-FY-CHO, IR, or both. (B) p65 protein immunofluorescence in in U251-consh and U251-Lsh cells treated with IR (10 Gy).

L-mediated modulation of the NF-kB signaling pathways has not been well studied. Thus, the interaction between cathep$\sin \mathrm{L}$ and NF-kB remains unclear.

Here, we demonstrated a relationship between cathepsin $\mathrm{L}$ and NF- $\mathrm{kB}$, confirming that cathepsin $\mathrm{L}$ affects the radiosensitivity of U251 cells via the regulation of NF-KB signaling. We established NF-kB knockdown U251 cell lines by using p65 shRNA. Unsurprisingly, no distinction in the basal expression level of cathepsin L was observed between U251-p65sh cells and irradiated or control RNA transfected cells, which means that the inhibition of NF-kB had no significant impact on the expression of cathepsin L in U251 cells.

To further understand cathepsin L's mechanism of action, we tested the extent of DNA damage following IR. The results of alkaline comet assays and clonogenic cell survival experiments suggested that IR-induced DNA damage repair and clonogenic cell survival in U251 cells were significantly decreased when NF-kB was inhibited, respectively, implying increased radiosensitivity of U251 cells; however, there was no notable difference between irradiated and nonirradiated U251p65sh cells at the level of DNA damage repair or clonogenic cell survival. Thus, we observed that NF-kB is closely related to radioresistance but has little impact on the expression of cathepsin L in U251 cells.

However, studies working to elucidate the exact mechanisms involved in cathepsin $\mathrm{L}$ regulation of NF-kB pathway regulation are still needed. Further understanding of how the cathepsin L pathway works may provide new insights into the cancer process. Because the activity of NF-kB is tightly regulated by interaction with inhibitory $I_{\kappa} B$ proteins, it is presumed that cathepsin $\mathrm{L}$ is involved in the proteolysis of $\mathrm{I} \kappa \mathrm{Ba}$, which in turn accelerates the activation of NF- $\mathrm{KB}^{[30]}$. Moreover, active cathepsin L (26 kDa) can translocate to the nucleus to mediate the proteolytic processing of CUX1 to generate p110 CUX1, which is the active form of full-length p200 CUX1 ${ }^{[33,34]}$. CUX1 plays an important role in the transcriptional regulation of chemotactic factors that are mediated by NF- $\mathrm{KB}^{[35]}$. Furthermore, CUX1 regulates ATM expression in response to DNA damage by binding to the promoter of the DDR gene ATM; this demonstrates that CUX1 is required for ATM-/ATRmediated cellular responses to genotoxic stress following IR exposure $^{[36]}$. Cathepsin L most likely regulates the activity of NF-kB and its downstream effectors via the CUX1 pathway.

It is likely that cathepsin L participates in NF-kB mediated radioresistance through several other correlating mechanisms to mediate CUX1 as well. For instance, $\beta$-Catenin, a key medi- 
A

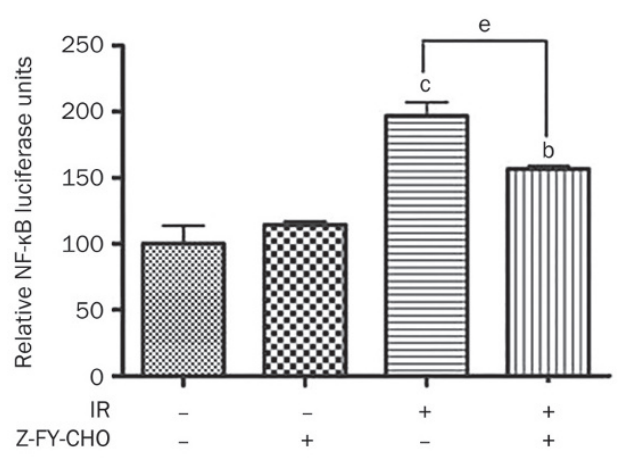

C
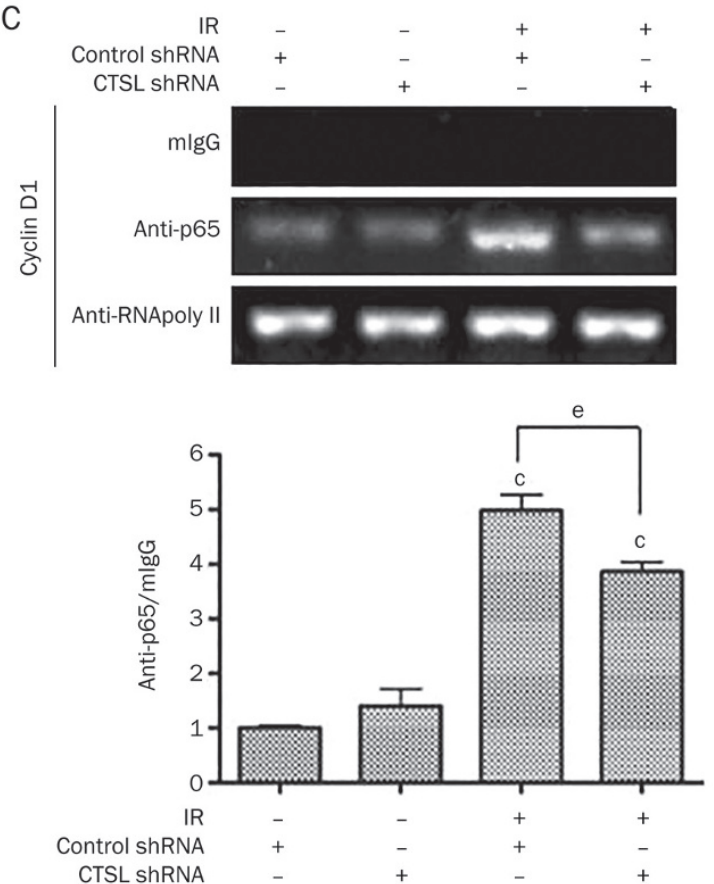

B

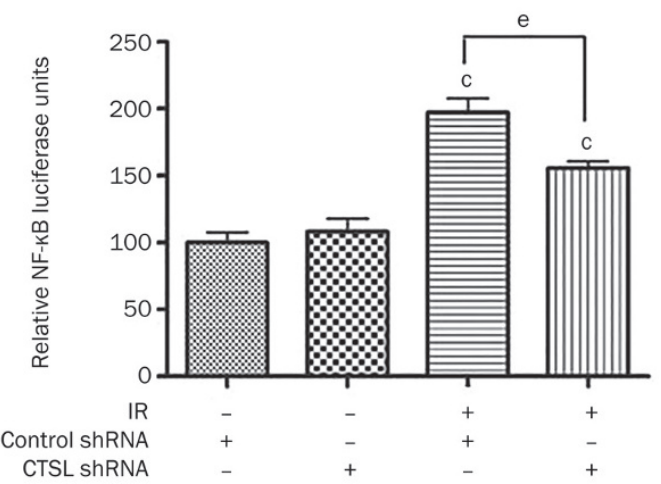

D
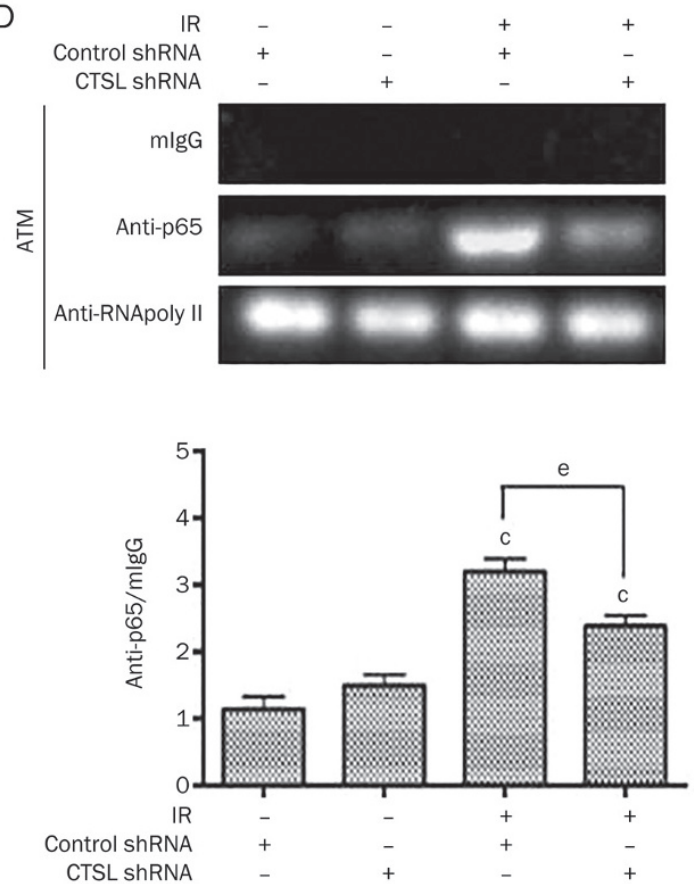

Figure 5. Reduced NF-KB-dependent transcriptional activation in U251 cells following IR with selective inhibition of cathepsin L with Z-FY-CHO (A) or cathepsin L shRNA (B). NF-kB activity was assessed using an NF-KB-RE firefly luciferase reporter vector (Promega). For normalization, cells were cotransfected with a constitutive Renilla luciferase reporter (Promega). ${ }^{b} P<0.05,{ }^{c} P<0.01$ vs control. ${ }^{e} P<0.05$ vs IR alone group. X-ray (10 Gy) exposure enhanced the recruitment of NF-KB to the cyclin D1 and ATM promoters in U251 cells, while the radiation-induced recruitment was reduced by inhibiting cathepsin L. (C) U251-consh and U251-Lsh cells were examined by ChIP assays with and without IR treatment. The recruitment of NF$\mathrm{KB}$ to the cyclin D1 promoter in U251 cells is shown. (D) Recruitment of NF-KB to the ATM promoter in U251-consh and U251-Lsh cells. Chromatin was immunoprecipitated with mouse IgG (negative control), antibodies to p65 and RNA polymerase II (positive control). The derived fragments were amplified by real-time PCR. ${ }^{c} P<0.01$ vs control shRNA group. ${ }^{\text {e }} P<0.05$ vs control shRNA plus IR group.

ator in the Wnt pathway, is a novel target of CUX1 $1^{[37,38]}$. Differential crosstalk exists between $\beta$-catenin/Tcf and the NF-kB pathway in various cancer types, which has implications on the mechanism described above ${ }^{[39]}$ and provides a mechanistic link between the Wnt cascade and NF-KB activation ${ }^{[40]}$.

Some articles have posited that cathepsin L is conditionally regulated by NF- $\mathrm{kB}$ when the cells were in mitochondrial respiratory stress ${ }^{[31,32]}$. However, we recently found the opposite regulatory mechanism--that cathepsin L contributes to NF-KB activation in the presence of quinolinic acid in rat striatal neurons. How these signals respond to radiation may vary under different conditions. Thus, it is reasonable for us to speculate that cathepsin L could also act on nuclear transcriptional factors and then regulate the activity of NF-kB either directly or indirectly.

The interaction between the NF-kB and cathepsin L pathways occurs at multiple cellular levels. The results of our study show that the modulation of the cathepsin L signaling pathway affects NF-kB signaling in U251 cells. Cathepsin L most likely has other interaction partners and functions in a complex network to regulate NF-kB pathways. In this report, we present a new interaction modality for the two radio-asso- 
A
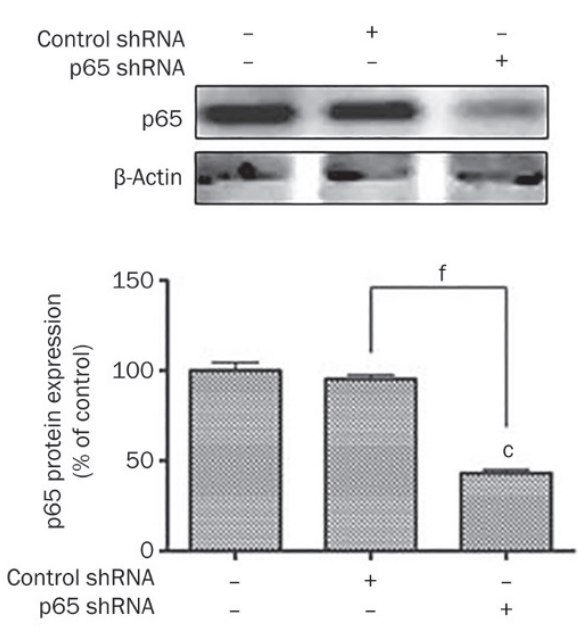

C
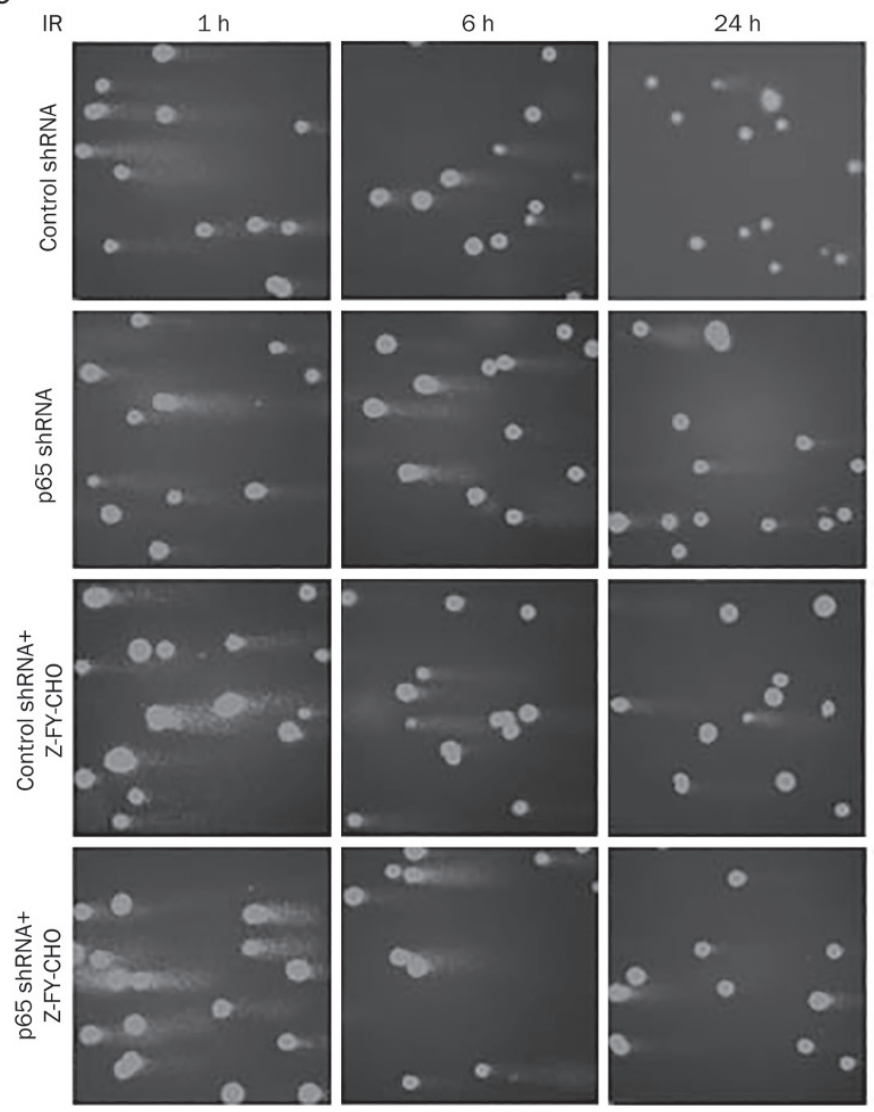

B
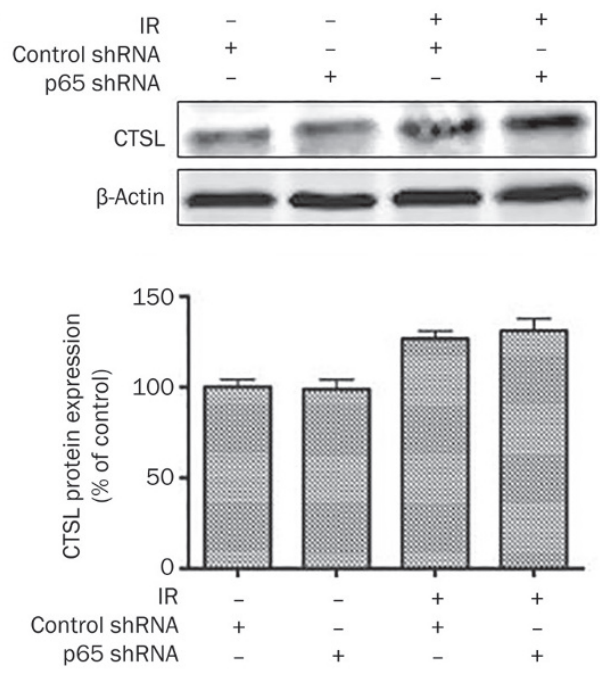

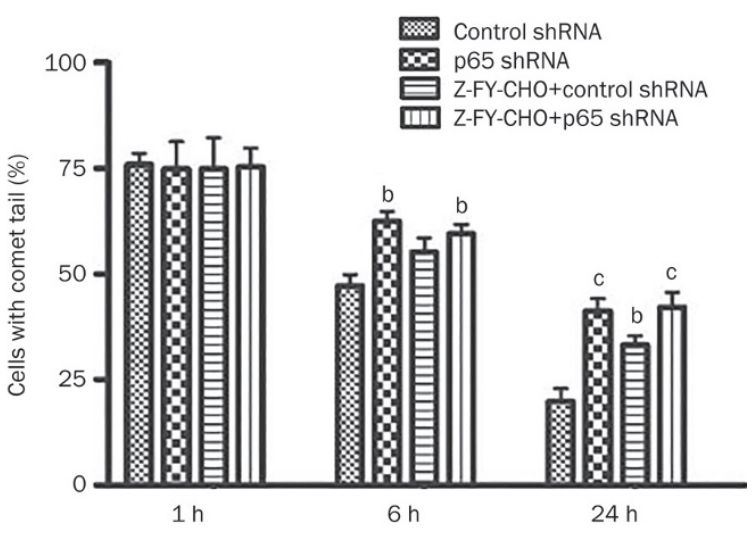

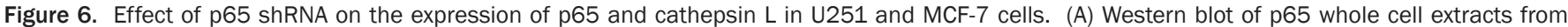

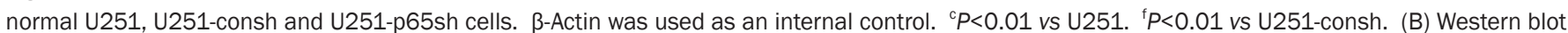

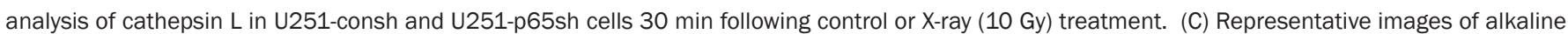

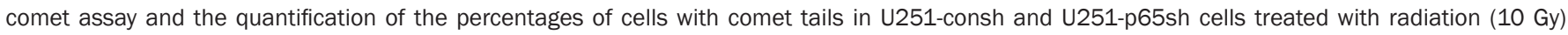
alone or in combination with Z-FY-CHO. ${ }^{b} P<0.05,{ }^{c} P<0.01$ vs U251-consh group at the relative time points.

ciated proteins in U251 cells under genotoxic stress induced by IR.

In summary, our study identified that cathepsin L plays an important role in mediating NF-KB activation and contributes to radioresistance in U251 cell lines. The inhibition of cathepsin $\mathrm{L}$ can reduce NF- $\mathrm{KB}$ activation to enhance IR-induced cytotoxicity, which makes it a potential target for tumor radiotherapy. 


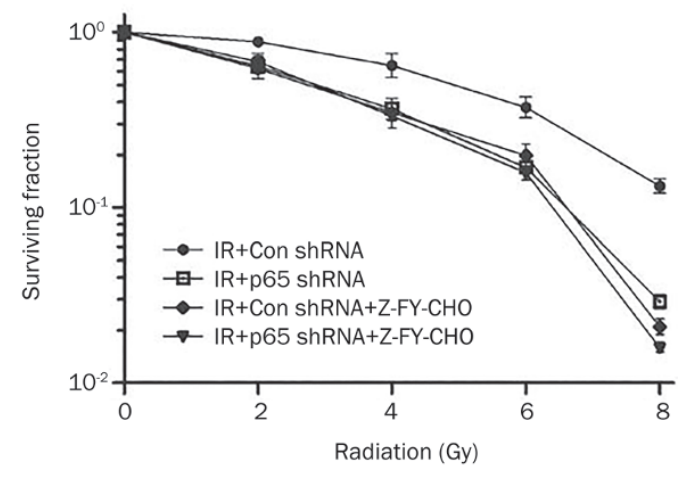

Figure 7. Clonogenic survival curves for U251-p65sh cells treated with radiation $(0,2,4,6$, and $8 \mathrm{~Gy})$ alone or in combination with Z-FY-CHO.

\section{Acknowledgements}

This study was supported by grants from the National Natural Science Foundation of China (Grant No 81072656, 81102466, and 81373430) and the Priority Academic Program Development (PAPD) of the Jiangsu Higher Education Institutions (Key Medical Department of Jiangsu Province in 2011).

\section{Author contribution}

Zhong-qin LIANG designed research; Neng YANG, Pan WANG, Wen-juan WANG, and Yun-zhen SONG performed research; Neng YANG analyzed data; Neng YANG and Pan WANG wrote the paper.

\section{References}

1 Tsai MH, Cook JA, Chandramouli GV, DeGraff W, Yan H, Zhao S, et al. Gene expression profiling of breast, prostate, and glioma cells following single versus fractionated doses of radiation. Cancer Res 2007; 67: 3845-52.

2 Zheng M, Morgan-Lappe SE, Yang J, Bockbrader KM, Pamarthy $D$, Thomas $D$, et al. Growth inhibition and radiosensitization of glioblastoma and lung cancer cells by small interfering RNA silencing of tumor necrosis factor receptor-associated factor 2 . Cancer Res 2008; 68: 7570-8.

3 Madhusoodhanan R, Natarajan M, Veeraraghavan J, Herman TS, Aravindan N. NFkappaB activity and transcriptional responses in human breast adenocarcinoma cells after single and fractionated irradiation. Cancer Biol Ther 2009; 8: 765-73.

4 Wang CY, Mayo MW, Baldwin AS Jr. TNF- and cancer therapy-induced apoptosis: potentiation by inhibition of NF-kappaB. Science 1996; 274: 784-7.

5 Yamagishi N, Miyakoshi J, Takebe H. Enhanced radiosensitivity by inhibition of nuclear factor kappa B activation in human malignant glioma cells. Int J Radiat Biol 1997; 72: 157-62.

6 Deng JO, Miller SA, Wang HY, Xia WY, Wen Y, Zhou BHP, et al. Betacatenin interacts with and inhibits NF-kappa B in human colon and breast cancer. Cancer Cell 2002; 2: 323-34.

7 Cao YX, Karin M. NF-kappa B in mammary gland development and breast cancer. J Mammary Gland Biol Neoplasia 2003; 8: 215-23.

8 Ghosh S, Karin M. Missing pieces in the NF-kappaB puzzle. Cell 2002; 109: S81-96.

9 Russell JS, Raju U, Gumin GJ, Lang FF, Wilson DR, Huet T, et al. Inhibition of radiation-induced nuclear factor-kappaB activation by an anti-Ras single-chain antibody fragment: lack of involvement in radiosensitization. Cancer Res 2002; 62: 2318-26.

10 Brach MA, Hass R, Sherman ML, Gunji H, Weichselbaum R, Kufe D. Ionizing radiation induces expression and binding activity of the nuclear factor kappa B. J Clin Invest 1991; 88: 691-5.

$11 \mathrm{Wu}$ JT, Kral JG. The NF-kappaB/IkappaB signaling system: a molecular target in breast cancer therapy. J Surg Res 2005; 123: 158-69.

12 Aravindan N, Madhusoodhanan R, Ahmad S, Johnson D, Herman TS. Curcumin inhibits NF kappa B mediated radioprotection and modulate apoptosis related genes in human neuroblastoma cells. Cancer Biol Ther 2008; 7: 569-76.

13 Jung M, Dritschilo A. NF-kappa B signaling pathway as a target for human tumor radiosensitization. Semin Radiat Oncol 2001; 11 : 346-51.

14 Russo SM, Tepper JE, Baldwin AS, Liu R, Adams J, Elliott P, et al. Enhancement of radiosensitivity by proteasome inhibition: Implications for a role of NF-kappa B. Int J Radiat Oncol Biol Phys 2001; 50 : 183-93.

15 Criswell T, Leskov K, Miyamoto S, Luo GB, Boothman DA. Transcription factors activated in mammalian cells after clinically relevant doses of ionizing radiation. Oncogene 2003; 22: 5813-27.

16 Baldwin AS Jr. Series introduction: the transcription factor NF-kappaB and human disease. J Clin Invest 2001; 107: 3-6.

17 Gocheva V, Joyce JA. Cysteine cathepsins and the cutting edge of cancer invasion. Cell Cycle 2007; 6: 60-4.

18 Jedeszko C, Sloane BF. Cysteine cathepsins in human cancer. Biol Chem 2004; 385: 1017-27.

19 Kos J, Stabuc B, Schweiger A, Krasovec M, Cimerman N, KopitarJerala $\mathrm{N}$, et al. Cathepsins $\mathrm{B}, \mathrm{H}$, and $\mathrm{L}$ and their inhibitors stefin $\mathrm{A}$ and cystatin C in sera of melanoma patients. Clin Cancer Res 1997; 3 : 1815-22.

20 Zajc I, Hreljac I, Lah T. Cathepsin L affects apoptosis of glioblastoma cells: a potential implication in the design of cancer therapeutics. Anticancer Res 2006; 26: 3357-64.

21 Brix K, Dunkhorst A, Mayer K, Jordans S. Cysteine cathepsins: cellular roadmap to different functions. Biochimie 2008; 90: 194-207.

22 Levicar N, Nuttall RK, Lah TT. Proteases in brain tumour progression. Acta Neurochir (Wien) 2003; 145: 825-38.

23 Stoka V, Turk B, Schendel SL, Kim TH, Cirman T, Snipas SJ, et al. Lysosomal protease pathways to apoptosis. Cleavage of bid, not procaspases, is the most likely route. J Biol Chem 2001; 276: 3149-57.

24 Kos J, Lah TT. Cysteine proteinases and their endogenous inhibitors: Target proteins for prognosis, diagnosis and therapy in cancer (review). Oncol Rep 1998; 5: 1349-61.

25 Lah TT, Strojnik T, Levicar N, Bervar A, Zajc I, Pilkington G, et al. Clinical and experimental studies of cysteine cathepsins and their inhibitors in human brain tumors. Int J Biol Markers 2000; 15: 90-3.

26 Hazen LG, Bleeker FE, Lauritzen B, Bahns S, Song J, Jonker A, et al. Comparative localization of cathepsin $B$ protein and activity in colorectal cancer. J Histochem Cytochem 2000; 48: 1421-30.

27 Strojnik T, Kavalar R, Trinkaus M, Lah TT. Cathepsin L in glioma progression: Comparison with cathepsin B. Cancer Detect Prev 2005; 29: 448-55.

28 Lankelma JM, Voorend DM, Barwari T, Koetsveld J, Van der Spek AH, De Porto AP, et al. Cathepsin L, target in cancer treatment? Life Sci 2010; 86: 225-33.

29 Xiang B, Fei XF, Zhuang WZ, Fang Y, Qin ZH, Liang ZQ. Cathepsin L is involved in 6-hydroxydopamine induced apoptosis of SH-SY5Y neuroblastoma cells. Brain Res 2011; 1387: 29-38.

30 Wang YR, Qin S, Han R, Wu JC, Liang ZQ, Qin ZH, et al. Cathepsin L 
plays a role in quinolinic acid-induced NF-Kappab activation and excitotoxicity in rat striatal neurons. PLoS One 2013; 8: e75702.

31 Biswas G, Tang W, Sondheimer N, Guha M, Bansal S, Avadhani NG. A distinctive physiological role for IkappaBbeta in the propagation of mitochondrial respiratory stress signaling. J Biol Chem 2008; 283 : 12586-94.

32 Guha M, Fang JK, Monks R, Birnbaum MJ, Avadhani NG. Activation of Akt is essential for the propagation of mitochondrial respiratory stress signaling and activation of the transcriptional coactivator heterogeneous ribonucleoprotein A2. Mol Biol Cell 2010; 21: 357889.

33 Goulet B, Nepveu A. Complete and limited proteolysis in cell cycle progression. Cell Cycle 2004; 3: 986-9.

34 Fragiadaki M, Ikeda T, Witherden A, Mason RM, Abraham D, BouGharios G. High doses of TGF-beta potently suppress type I collagen via the transcription factor CUX1. Mol Biol Cell 2011; 22: 1836-44.

35 Ueda Y, Su Y, Richmond A. CCAAT displacement protein regulates nuclear factor-kappa beta-mediated chemokine transcription in melanoma cells. Melanoma Res 2007; 17: 91-103.
36 Vadnais C, Davoudi S, Afshin M, Harada R, Dudley R, Clermont PL, et al. CUX1 transcription factor is required for optimal ATM/ATRmediated responses to DNA damage. Nucleic Acids Res 2012; 40: 4483-95.

37 Ripka S, Konig A, Buchholz M, Wagner M, Sipos B, Kloppel G, et al. WNT5A--target of CUTL1 and potent modulator of tumor cell migration and invasion in pancreatic cancer. Carcinogenesis 2007; 28: 117887.

38 Katoh M. Transcriptional mechanisms of WNT5A based on NFkappaB, Hedgehog, TGFbeta, and Notch signaling cascades. Int J Mol Med 2009; 23: 763-9.

39 Cho HH, Song JS, Yu JM, Yu SS, Choi SJ, Kim DH, et al. Differential effect of NF-kappa B activity on beta-catenin/Tcf pathway in various cancer cells. FEBS Lett 2008; 582: 616-22.

40 Wang X, Adhikari N, Li Q, Guan Z, Hall JL. The role of [beta]-transducin repeat-containing protein (beta-TrCP) in the regulation of NF-kappaB in vascular smooth muscle cells. Arterioscler Thromb Vasc Biol 2004; 24: 85-90. 